\title{
To Push or To Clip: That is the Question 1
}

\author{
Stephen H. Futch, James H. Graham and Larry W. Duncan²
}

For the past 5 to 10 years, many citrus growers have wondered whether it is better to remove the entire tree and root system by pushing or whether clipping the tree off above the soil line is an acceptable alternative method to remove diseased or unproductive citrus trees from groves. Growers have expressed both positive and negative observations about each tree removal method. Therefore, a review and evaluation of the potential benefits and drawbacks of each method is appropriate.

\section{Pushing Trees}

The perceived advantages of pushing the tree and removing the root system from the soil are: 1) most of the infested root system is removed from the soil, thereby reducing future disease and pest pressure created by the existing root system; 2) the site is easier to replant when the soil is free of roots; 3 ) mixing the soil when uprooting the tree may facilitate the establishment of a newly planted tree and root system; and 4) tree spacing within the row is not altered because the new tree is replanted exactly where the old tree was removed (Fig. 1).

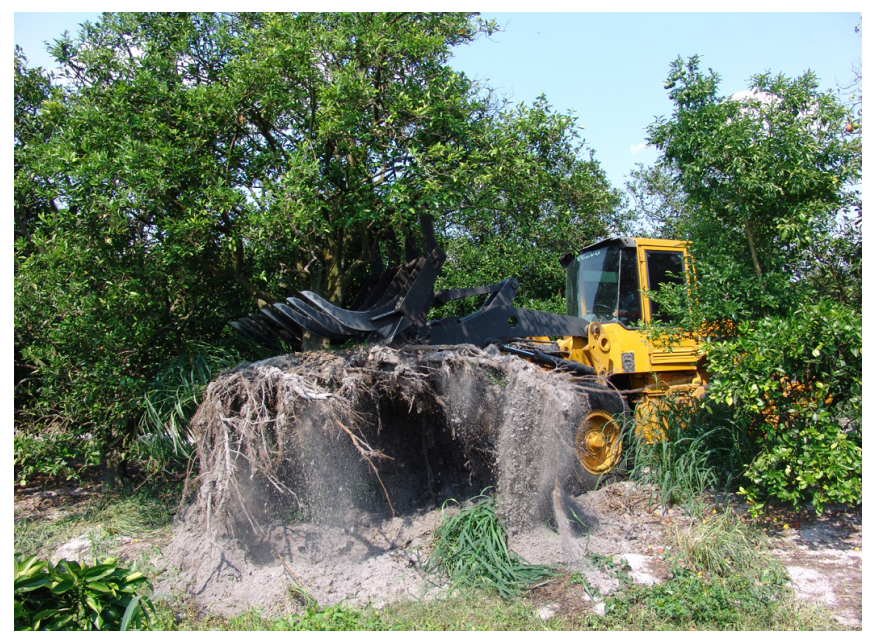

Figure 1. Pushing a citrus tree.

The perceived disadvantages for pushing are: 1) cost of tree removal is higher than that of clipping because it takes longer to remove and dispose of the entire tree than just the above ground portion; 2) poly irrigation lines may be damaged when the roots are removed from the soil thereby necessitating labor and expense to cut, move, and reconnect the irrigation line before and after tree removal; 3 ) in some cases, soil must be replaced to restore the elevation of the replanting site when a depression is formed by removal of the root system, adding to the expense of

1. This document is HS1065, one of a series of the Horticultural Sciences Department, Florida Cooperative Extension Service, Institute of Food and Agricultural Sciences, University of Florida. Published June 2006. Visit the EDIS Web site at http://edis.ifas.ufl.edu.

Acknowledgement. This study was supported by the Florida Citrus Production Research Advisory Council.

2. S.H. Futch, extension agent IV, Horticultural Sciences Department; J.H. Graham, professor, Soil and Water Science Department; L.W. Duncan, professor, Entomology and Nematology Department; Citrus REC, Lake Alfred, Florida; Cooperative Extension Service, Institute of Food and Agricultural Sciences, University of Florida, Gainesville, 32611.

The Institute of Food and Agricultural Sciences (IFAS) is an Equal Opportunity Institution authorized to provide research, educational information and other services only to individuals and institutions that function with non-discrimination with respect to race, creed, color, religion, age, disability, sex, sexual orientation, marital status, national origin, political opinions or affiliations. U.S. Department of Agriculture, Cooperative Extension Service, University of Florida, IFAS, Florida A. \& M. University Cooperative Extension Program, and Boards of County Commissioners Cooperating. Larry Arrington, Dean 
tree replanting; and 4) the bed integrity may be compromised when trees are removed in bedded groves.

\section{Clipping Trees}

The perceived advantages of clipping trees are: 1) the cost is lower than that of pushing because the process is quicker and less material is disposed of; 2) lateral irrigation lines are usually not damaged when the trees are clipped; 3 ) the elevation of the site is not altered where the tree is removed; and 4) beds are not damaged when the tree is removed (Fig. 2).

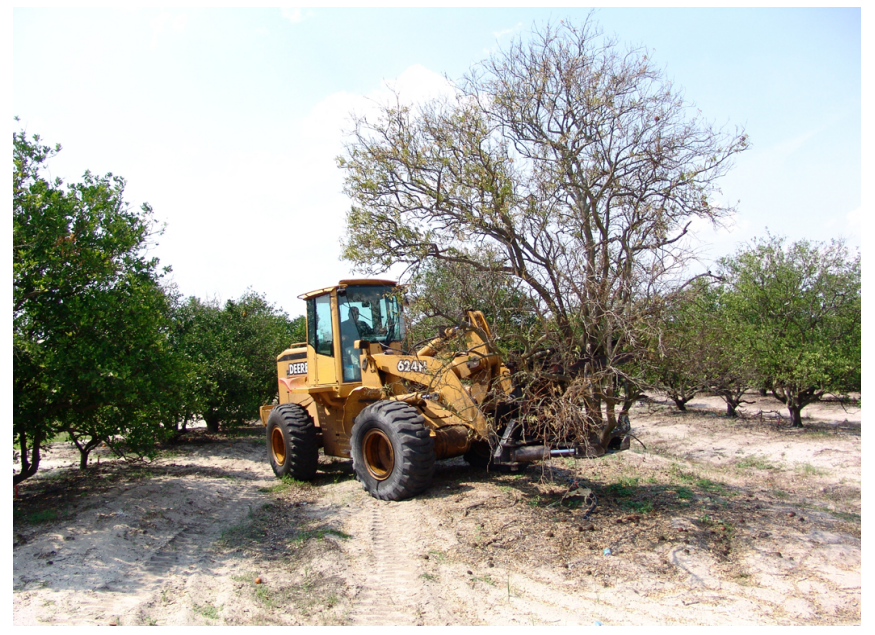

Figure 2. Clipping a citrus tree.

The perceived disadvantages of clipping are: 1) the intact root system in the soil can harbor pests and pathogens which may quickly infect the young replant; 2) roots remaining in the site make replanting the tree more difficult; 3 ) trees are no longer equally spaced in the row because it is necessary to move the new tree one or more feet away from the remaining tree stump; 4) Ganoderma, a wood-rotting fungus, infects stumps and may infect the adjacent replant; 5) root sprouts from the remaining stump can create a significant expense for chemical applications after replanting and; 6) in some cases, the material used to treat and kill the stump may be translocated into the adjacent tree via natural root grafting.

\section{Tree Replant Studies}

To investigate the concerns about the push and clip methods, a study was initiated in the summer of 2002 in three groves in separate production regions.
The groves were located in Polk, DeSoto, and western St. Lucie Counties to represent the three major citrus production regions, i.e. the central ridge, and the flatwoods area of the southwest and east coast of Florida. At each grove site, 36 to 48 pairs of adjacent declining trees were removed by randomly pushing one and clipping the other. When trees were pushed, a front end loader was used to remove the entire tree and as much of the root system from the soil as possible, leaving the site nearly root free. Clipped trees were sheared with a standard tree shearer about 6 inches to 1 foot above the soil surface, leaving the entire root system intact in the soil. After clipping, the participating growers applied materials to kill the stump to minimize stump or root sprouting. Within 2 to 6 months after removing the trees, resets were planted in the pushed sites or within 1 to 2 feet of the adjacent clipped stump. Shortly after planting, all tree trunks were measured at a height of 2 inches above the budunion and then measured each year thereafter. Also, at the time of replanting and at the end of the first and second year, soil was analyzed for Phytophthora and plant parasitic nematodes. Soil samples consisted of 10 soil cores to a depth of 1 foot taken at each replanted tree and analyzed at all three sites and then annually thereafter at the ridge site. The flatwoods sites where the nematode levels were not significant had composite samples collected beginning in the third year. All reset sites were visually evaluated for the presence or absence of Ganoderma fungi on roots or remaining tree stumps. Statistical tests were then conducted to compare differences between clipped and pushed sites at each location.

Over the study period at all three sites, nearly all citrus stumps were found to be infected with one or more Ganoderma fungi. However, only one replant tree was found to be infected, which indicates that tree removal by clipping did not significantly affect the number of replant trees infected with Ganoderma.

In general, the combined results from all three sites indicated that young tree growth in trunk diameter (Figs. 3a, 4a, \& 5a) was similar for both removal methods. Longer term evaluations would be required to demonstrate any negative effect. 


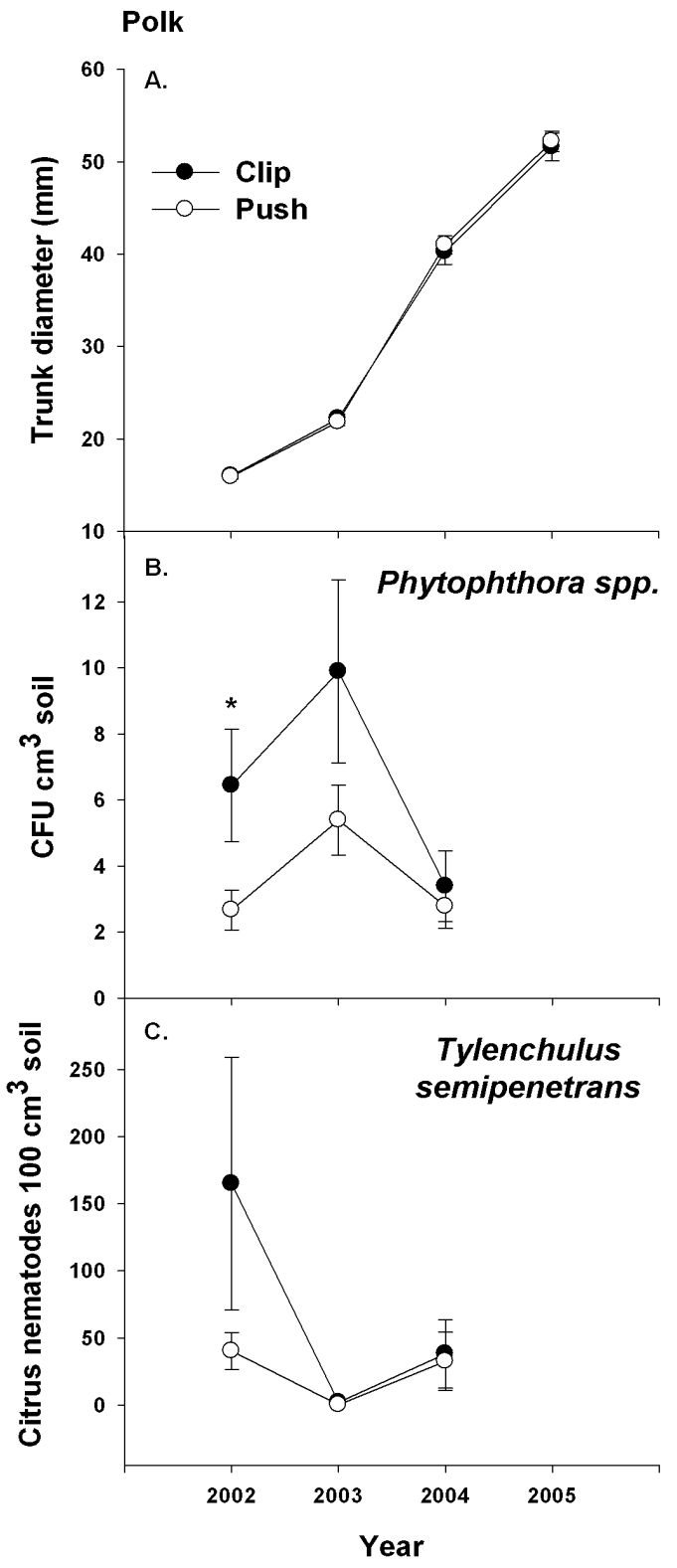

Figure 3. Polk County young tree replant site. ${ }^{*} \mathrm{CFU} \mathrm{cm}^{3}$ $=$ Colony Forming Units per cubic centimeter. Tree removal method - Clip $=$ cutting the tree off above soil line; Push = removing tree and root system from soil.

Citrus nematodes (Tylenchulus semipenetrans) were present at only one site. At the ridge location, citrus nematode populations were significantly higher in the clipped- than the pushed-tree sites in the first year, but not thereafter (Fig. 3c). Clipped trees initially supported significantly higher population levels of Phytophthora at the Polk and DeSoto County groves (Figs. $3 b$ \& $4 b$ ). At these sites, the level of Phytophthora approached or exceeded damaging levels on clipped trees (>10 propagules), but differences between removal methods disappeared

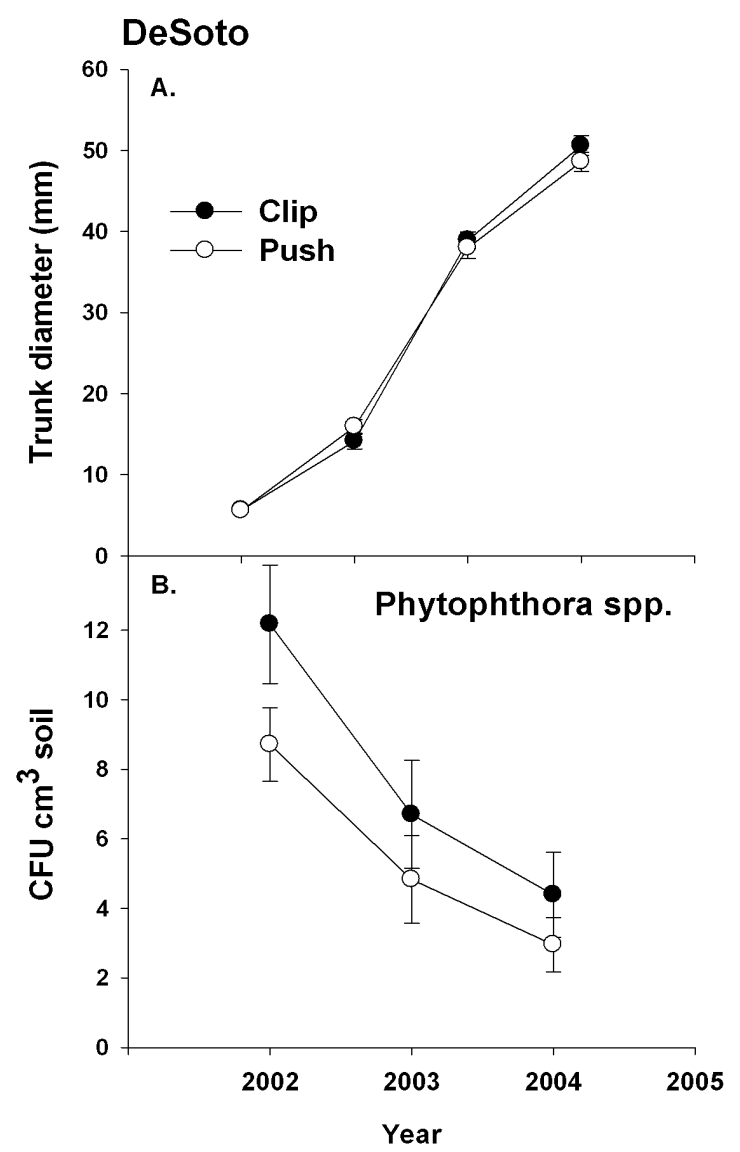

Figure 4. DeSoto County young tree replant site. ${ }^{*} \mathrm{CFU}$ $\mathrm{cm}^{3}=$ Colony Forming Units per cubic centimeter. Tree removal method - Clip = cutting the tree off above soil line; Push = removing tree and root system from soil.

within 1 to 2 years. Phytophthora levels were not affected by tree removal methods at the St. Lucie grove.

Based on these data and other field observations, tree removal by either pushing or clipping appears to have similar effects on the subsequent performance of young replants. Therefore, the method of tree removal growers choose should depend only on operational and economical considerations. 


\section{St. Lucie}

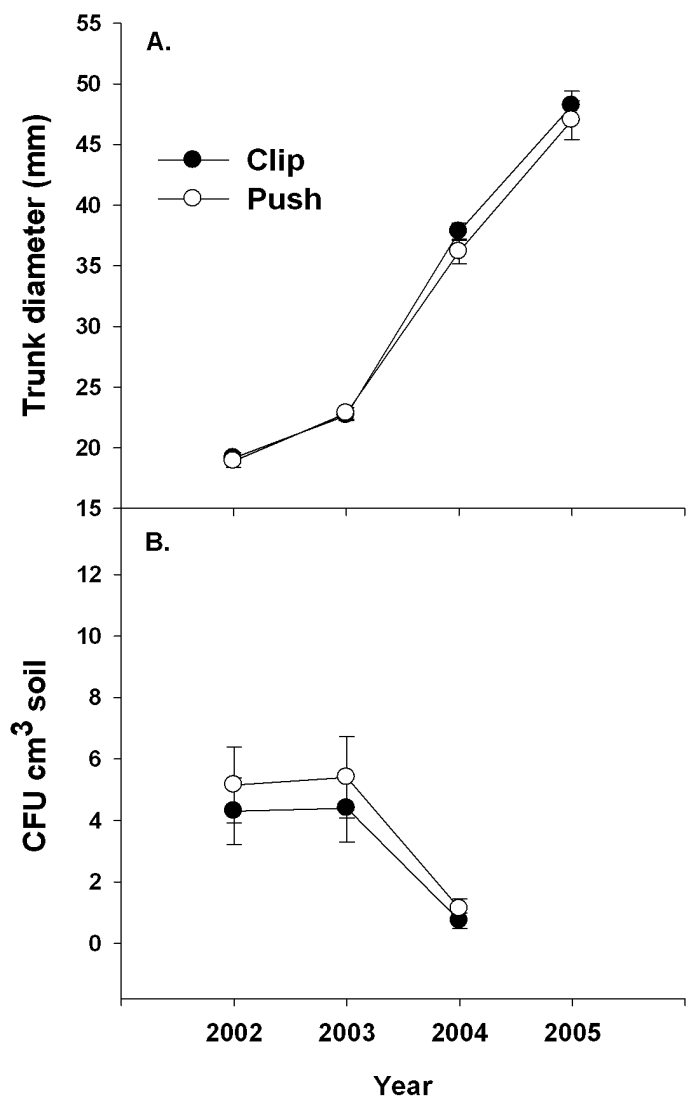

Figure 5. St. Lucie County young tree replant site. ${ }^{*} \mathrm{CFU}$ $\mathrm{cm}^{3}=$ Colony Forming Units per cubic centimeter. Tree removal method - Clip $=$ cutting the tree off above soil line; Push = removing tree and root system from soil. 